\title{
RESEARCH IN SPORT \\ PHYSICAL ACI \\ Macrophages during skeletal muscle regeneration: from experimentation in mouse to human physiology
}

\author{
Autor(es): $\quad$ Chazaud, Bénédicte
}

Publicado por: Imprensa da Universidade de Coimbra

URL persistente:

URI:http://hdl.handle.net/10316.2/44071

DOI:

DOI:https://doi.org/10.14195/2182-7087_ex2018_8

Accessed : $\quad$ 26-Apr-2023 16:24:45

A navegação consulta e descarregamento dos títulos inseridos nas Bibliotecas Digitais UC Digitalis, UC Pombalina e UC Impactum, pressupõem a aceitação plena e sem reservas dos Termos e Condições de Uso destas Bibliotecas Digitais, disponíveis em https://digitalis.uc.pt/pt-pt/termos.

Conforme exposto nos referidos Termos e Condições de Uso, o descarregamento de títulos de acesso restrito requer uma licença válida de autorização devendo o utilizador aceder ao(s) documento(s) a partir de um endereço de IP da instituição detentora da supramencionada licença.

Ao utilizador é apenas permitido o descarregamento para uso pessoal, pelo que o emprego do(s) título(s) descarregado(s) para outro fim, designadamente comercial, carece de autorização do respetivo autor ou editor da obra.

$\mathrm{Na}$ medida em que todas as obras da UC Digitalis se encontram protegidas pelo Código do Direito de Autor e Direitos Conexos e demais legislação aplicável, toda a cópia, parcial ou total, deste documento, nos casos em que é legalmente admitida, deverá conter ou fazer-se acompanhar por este aviso. 


\section{ANNALS OF RESEARCH IN SPORT AND PHYSICAL ACTIVITY}




\title{
MACROPHAGES DURING SKELETAL MUSCLE REGENERATION: FROM EXPERIMENTATION IN MOUSE TO HUMAN PHYSIOLOGY
}

\author{
Bénédicte Chazaud ${ }^{1}$
}

KEY WORDS: Muscle regeneration, inflammation, macrophages

Inflammation after a tissue damage encompasses several sequential phases including: 1) the mounting of the inflammatory response, characterized by the infiltration of immune cells to the site of injury and the release of proinflammatory effectors; 2) the resolution of inflammation, characterized by a shift from a proinflammatory environment to the establishment of the anti-inflammatory phase of inflammation; and 3) tissue repair/regeneration including angiogenesis, matrix remodeling and return to homeostasis. Almost all immune cell types participate in this inflammatory process. However, macrophages are present in high number and during all the sequences of the inflammatory response. Because of their high versatility and their impact on their environment, they sustain both the mounting and the dampening of the inflammatory response. Accumulating lines of evidence of the beneficial - and pleiotropic roles - of macrophages in tissue repair indicate that inflammation should not be considered as a bad or detrimental process. Conversely, it should be viewed as a dynamic process of which sequential steps must be tightly coordinated in space and time to be fully efficient to support skeletal muscle regeneration.

Most of the knowledge on the role of inflammation during skeletal muscle regeneration comes from mouse experimental models that use toxic injury. Although not physiologically relevant, this type of injury offers the advantage of being highly reproducible, the kinetics of each step of muscle regeneration being well characterized. Moreover, these models are highly inflammatory, which is useful to study inflammation.

The overall role of macrophages during skeletal muscle regeneration will be presented, as well as the sustaining molecular mechanism of their own regulation and the regulation of myogenesis. Then, some elements will be presented to open the discussion on the link

1 Institut NeuroMyoGène, UMR CNRS 5310 - INSERM U1217, Université Claude Bernard Lyon, France 
between the knowledge obtained from experimentation in small animals and human physiology, notably in the context of Exercise-Induced Muscle Injury (EIMD). 